\title{
The Determinants of Capital Structures in Automotive and Component Industries as Listed in IDX (Indonesia Stock Exchange)
}

\author{
Dani Triantoro $^{\# 1}$, Eka Bertuah ${ }^{\# 2}$ \\ ${ }^{\#}$ Esa Unggul University, Jakarta
}

\begin{abstract}
This study was conducted to determine the determinants of capital structure in the automotive industry and components, and provide the evidence of whether the capital structure influences the company value. The study was done on 12 automotive companies and components as listed Indonesia Stock Exchange (IDX) from 2008 to 2017. The data analysis using logistic regression and different tests. The results of this study indicate that the determinants of capital structure in the automotive industry and components are profitability and sales growth. The research result also prove that there is no different firm value between the company with high debts funding and low debts funding structures. This gives empirical support totrade off theory from Modigliani and Miller.
\end{abstract}

Keywords: capital structure, profitability, market capitalization, interest rates and firm value.

\section{INTRODUCTION}

Company decision not only achieves the maximum value goal but also pays attention to negotiations to improve product competitiveness(Li \& Wang, 2019)A company can increase the competitiveness of its products by expanding market share, differentiating products, and increasing sales distribution (Deari \& Deari, 2010). To do that the company is required to have sufficient capital. A company with sufficient capital can seize market share from its competitors through the development and expansion of the sales network (Palacín-Sánchez et al., 2013). However, because of opportunity costs, companies usually have limited cash ownership and as such, capital demands cannot always be met (Li \& Wang, 2019). Companies with strong financing capacities are more likely to occupy favorable positions in the market. In choosing a reasonable capital structure a strong financing capacity is very important for the company for its long-term development. According to the pecking order theory, the companies tend to choose internal funding than the external funding(Shah \& Ilyas, 2014). The trade off theory states that companies switch the tax benefits from debt funding with the problems caused by potential bankruptcy(Anuar \& Chin, 2016).

Determining the capital structure will be influenced by internal and external factors of the company. The relationship between capital structure and profitability cannot be ignored because the increase of profitability is needed for the long-term survival of the company(Gill et al., 2011). Profitability is the company's ability to generate net profit consistently(Velnampy \& Aloy Niresh, 2012). There are several results of research on the effect of profitability on capital structure in companies. The results of research Huang et al., (2011), Usman \& Saleem (2015) and Orsag \& Mitar (2014) say same thing that profitability has a positive and not significant effect on capital structure. In contrast to the results of research Khaled Ba-Abbad \& Ahmad-Zaluki(2012), Nha et al., (2016) and Velnampy \& Aloy Niresh (2012) showed profitability had a negative and not significant effect on capital structure.

According to cortez and stevie (2012), one of the factors that determines the company's capital structure is the company's growth. It can be seen that a growing company needs funds to carry out its operational activities. The growth in a company includes growth in sales, profits, and assets. Sales growth is the difference between the number of sales in the current period with the previous period divided to the sales in the previous period. According to Said (2013), if the company's sales growth increase, the company's capital structure will also increase. The high sales growth rate means the sales volume is increased, so the production capacity needs to be improved. The results of Orsag \& Mitar (2014) and Faez \& Kalantari (2015) research show that sales growth has a positive and not significant effect on capital structure. While research Nha et al., (2016),Mangafić \& 
Martinović (2015) and Anuar \& Chin (2016) research results show that sales growth has a negative and not significant effect on capital structure.

While making the investment decisions, the investors assume that large companies are relatively stable and will be able to create more profits compared to the smaller companies. According to mac an Bhaird \& Lucey(2010), the company size is one of the variables affecting the capital structure. Usually, the large companies prefer to get capital from long-term debts while the small companies prefer to get capital using shortterm debts. Meanwhile according to Nha et al., (2016),the capital structure of large companies will have more leverage than small companies. The relationship between the company size and leverage is essential to be fullyunderstoodas the large companies have the tendency to diversify their financial sources compared to smaller companies. The larger the size of the company, themore investors to pay attention to the company. The results of Anuar \& Chin (2016) and Deari \& Deari(2010) show that sales growth has a positive and not significant effect on capital structure. While researchKumar \& Rao(2016) and Chen (2015)their results say the size of the company has a negative and not significant effect on capital structure.

The interest rate is generally used as a measure of capital costs that must be incurred to obtain funds from the capital owners (creditors). $\mathrm{Zia}(2016)$ stated that high interest rates on debt causing the decrease in profitability. Viewed from the company's perspective, the interest rate is one of the capital costs for the company, so the rising interest rates add more burden to the cost that must be supported by the company. Thus, when interest rates increase, the management will respond by adjusting the level of capital structure to reduce the financial burden that must be paid. The results of Sedláček \& Němec(2018)shows that interest rates have a positive and not significant effect on capital structure. Whereas Örtqvist et al., (2006) show that interest rates have a negative and not significant effect on the structure.

\section{Capital Structure}

\section{II.LITERATURE REVIEW}

The capital structure is the composition of ordinary shares, preferred shares, retained profit and long-term debt maintained by the business entity to fund the assets. Capital structure is an illustration of corporate financial proportion form between owned capital sourced from long term liabilities and shareholder's equity as the financing sourceof a company (Usman \& Saleem, 2015). Capital structure is a balance between the use of loan capital consisting of permanent short-term debt and long-term debt of owned capital consisting of preferred shares and ordinary shares(Kim, 2013). Funding needs to strengthen the company's capital structure can be gained internally and externally, but the funding source should come from the safe resource and if it is used, it should have value in strengthening the company's financial capital structure(Pattweekongka, 2014). When the funds are used to strengthen the company's capital structure, the company will be able to control the capital effectively and efficiently and also hit the target. According to Anuar \& Chin (2016), the capital structure ratio is Debt Equity Ratio (DER), this ratio is used to measure the balance between the liabilities of the company and its own capital. This ratio can be also interpreted as the company's ability to meet the obligation to pay its debts with their own capital as the guarantee. The measurement of capital structure with a proxy using debt to equity are as follows:

$$
\mathrm{DER}=\frac{\text { Total Liebilities }}{\text { Total Equity }} \times 100 \%
$$

\section{Factors Affecting Capital Structure Profitability (ROE)}

According to Ahmed Sheikh \& Wang (2011), profitability is the ability of companies to earn profits in relation to sales, total assets and own capital. Thus, long-term investors will be attracted in this profitability analysis. For example, the shareholders could see the profits that will be gained as dividends(Li \& Wang, 2019). To measure the profitability ratio in this research, the proxy of return on asset (ROA), return on equity (ROE) and gross profit margin (GPM) proxy is used. The ROA is chosen as a proxy for profitability due to the higher ROA ratio will show the more efficient the company in using its own assets to create profits. The measurement of the capital structure with the proxy using return on assets can be written as:

ROA : $\frac{\text { Earning After Tax }}{\text { Total Asset }}$


The selection of ROE as another profitability proxy is based on the profitability ratio assessing from the investor's perspective, not from the company's perspective. According to Orsag \& Mitar (2014), this ratio calculates on how much money a company can produce based on the money invested by shareholders, not the company's investment in the form of assets or something else. The formula used is the measurement of capital structure with a proxy using return on equity can be written as:

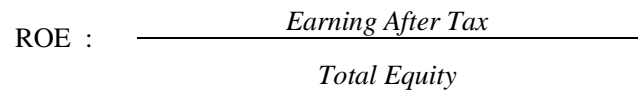

Gross profit margin is chosen as a proxy of profitability ratios because it could tell on how efficient a company uses its materials and labor to produce and sell its products to make a profit. This proxy is used to calculate the percentage of excess gross profit on sales revenue Ahmed Sheikh \& Wang(2011). Gross profit here referred to the difference between sales sold (COGS).

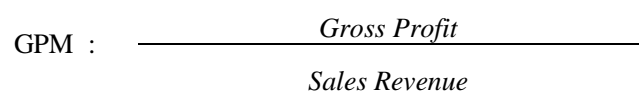
revenue and cost of goods

\section{Sales Growth}

Growth ratio is a ratio measuring on the company's ability to maintain its position in the industry and in economic development in general(cortez and stevie, 2012). Usman \& Saleem(2015) said that the company's growth rate had a negative effect on capital structure because companies with high sales growth prefer use their own capital or retained profit to finance their operational activities rather than using long-term debt. To meet their funding needs, the companies that have increasing sales do not always take funds from debt, but would rather use their own capital or retained profit. The measurement of capital structure with the proxy using sales growth as written below :

$$
\text { Growth Sales : } \frac{\text { Net sales }^{t}}{\text { Net sales }^{t-1}}
$$

\section{Market Capitalization}

Market value reflects the company's current wealth, a measure of company size(Anuar \& Chin, 2016). The bigger the market value, the bigger the size of the company is(M'ng et al., 2017). Companies that have bigger market value use a lot of debt so the capital structure is enlarged. While the small sized companies use less debt so the company's capital structure is scaled down. The measurement of capital structure with a proxy using market capitalization are as follows:

$$
\text { MC =Current Market Price (per share) } x \text { Total Number of outstanding shares }
$$

\section{Interest Rate (BI Rate)}

The interest rate is generally used as a measure of capital costs that must be paid to obtain funding from the capital owners (creditors). The interest rate is called loan interest (Sedláček \& Němec, 2018). Therefore, the interest rate is actually a price that is able to be paid by people who need money (debtors). The interest rate is formed in the money market and capital market. An increase in interest rates in general will make the stock price going down because it will cut the company profits, so indirectly, with an increase in interest rates the capital structure will go down(Mangafić \& Martinović, 2015). The measurement of capital structure with the proxies using interest rates can be written as:

Interest Rate $=\mathrm{BI}$ Rate ${ }_{\mathrm{t}}$

\section{Firm Value}

The firm value is the investor's perception of the company often associated with the shares price. The firm value formed through shares market indicators is strongly influenced by the investment opportunities(Faez \& Kalantari, 2015). Firm value is the actual value per share that will be received if the company's assets are sold according to the share price(Campus et al., 2017). This study using price earnings ratio (PER) proxy. According to Aggarwal \& Padhan (2017), PER shows how much money the investors are willing to spend to pay for each reported profit. The use of price earnings ratios is to see how the market values the company's performance as 
reflected by its earnings per share. The measurement of capital structure with a proxy used return on equity is written as:

$$
\text { PER : } \frac{\text { Price per Share }}{\text { Earnings per Share }}
$$

\section{HYPOTHESIS}

\section{The Relation between Profitability and Capital Structure}

The relationship between profitability and capital structure cannot be ignored because an increase in profitability is needed for the long-term survival of the company(Gill et al., 2011). Profitability is the company's ability to generate net profit, this ratio is used as a benchmark to evaluate the performance of a company and help summarize large amounts of financial data and make qualitative judgments about company profitability(M'ng et al., 2017).The companies that is experiencing financial difficulties will borrow money or issue their shares under certain conditions in order to obtain a source of funds for their operations. While companies with good financial conditions will borrow less money even though they have the opportunity to borrow more. This shows that the greater the profitability obtained by the company, the greater the capital structure of the company is. It is in line with the Pecking Order Theory stating that the companies tend to use internal funding as much as possible before deciding to owe some. Research by Velnampy \& Aloy Niresh (2012),Khaled Ba-Abbad \& Ahmad-Zaluki (2012), and Deari \& Deari (2010)were conducted to study the relationship between capital structure and profitability. The results of the analysis show that there is a negative relation between capital structure and profitability. This means that the company will use more of its own capital to carry out its operational activities to gain more profits. Based on the description above, the formed hypothesis is:

H1: Profitability has a negative effect on the company's capital structure.

\section{The Relation between Sales Growth and Capital Structure}

One of the factors influencing capital structure is sales growth. Companies with stable sales may take more debt and bear higher fixed costs compared to the companies with unstable sales. A company in the industry that has high growth rate must provide sufficient capital to fund the company's operations. Usman \& Saleem (2015) said that the company's growth rate had a negative effect on capital structure because companies with high sales growth preferred using their own capital or retained earnings to finance operational activities rather than use long-term debt. In order to meet the funding needs, the companies with increasing sales do not always take funds from debt but would rather use their own capital or retained earnings. The same results are shown from cortez and stevie (2012)and Nha et al., (2016). Based on the description above, the hypothesis formed is as follows:

H2: Sales growth negatively affects the company's capital structure.

\section{The Relation between Market Capitalization and Capital Structure}

According to Anuar \& Chin(2016)market value reflects the company's current wealth, which is a measurement of firm size. The greater the market value owned by the company, the greater the size of the company is. The companies that have a greater market value use a lot of debt, thereby it increases the capital structure. While the small sized company tends to use less debt, thereby it reduces the company's capital structure. Based on the partially research result, it can be seen that the size of the company has a positive and significant effect on capital structure. Firm size is one of the factors that will influence the increase or decrease in the value of capital structure. The larger the size of a company, the greater the capital needed, the more total assets owned by the company and the greater the tendency to use the company's external funding for operations. This is because big companies have large funding needs and in order to meet those needs, they should use the external funding.

According to $\operatorname{Kim}(2013)$, the greater the size of a company the easier it is for companies to obtain external funding. it is because the large assets owned by the company provide certain confidence for investors to invest their funds. It is similar to the creditors to lend the debt funds to the company. From that, the size of the company affects the amount of the debt that can be obtained and also affects the amount of debt needed by the company. Chen(2015) examined the determinants of capital structure and invented that firm size has a positive effect, which also supported by the researches by (mac an Bhaird \& Lucey, 2010), Nha et al., (2016),M'ng et al., (2017) and Deari \& Deari(2010). Based on the description above, the hypothesis formed is: H3: Market capitalization has a positive effect on the company's capital structure. 


\section{The Relation between Interest Rates and Capital Structure}

Interest rates are generally used as a measure of capital costs that must be incurred to obtain funds from the owners of capital (creditors)(Sedláček \& Němec, 2018). Therefore, the interest rate is actually a price that is willing to be paid by people who need money (debtors). Viewed from the perspective of the company, the interest rate is a component of the cost of capital for the company. So, the rising interest rates add more burden to costs that must be paid by the company. Graham \& Harvey (2001) and ÖRTQVIST et al., (2006) in their study found that obligation issuance occurs at a low interest rate. Thus, when interest rates increasing,the management will respond by adjusting the level of capital structure to reduce the financial burden that must be paid. Based on the description above, the hypothesis can be written as:

H4: Interest rates have a negative effect on the company's capital structure.

\section{The Relation Between Capital Structure to Firm Value}

Price earningsratio (PER) can identify the amount of rupiah that must be paid by investors to obtain one rupiah of corporate earnings(Faez \& Kalantari, 2015). In other words, PER is the price of each company earnings rupiah. In addition, PER is a measure of the relative price of a company's shares. According to Aggarwal \& Padhan (2017),investment decisions proxied by the price earnings ratio have a positive influence on capital structure. Investment decisions are decisions regarding the allocation of funds from the inside and outside of the company in various forms of investment. If the PER of the share is high, it can be said that the more expensive the share compared to the net income per share. The greater the PER, the higher the amount of the debt that the company has. To see the company's performance getting better investors usually look at an increase in PER from the company, an increase in PER is also impactful to attract the attention of prospective creditors(Kumar \& Rao, 2016). With the better engagement from the creditor to the company, it is very possible that the amount of the debt will increase(Li \& Wang, 2019). An increase in the amount of debt that is relatively large than the owned capital will increase PER. Based on the description above, the hypothesis can be written as:

H5: Firm Value has a positive effect on the company's capital structure.

Based on the research hypothesis described above, the research model can be described as:

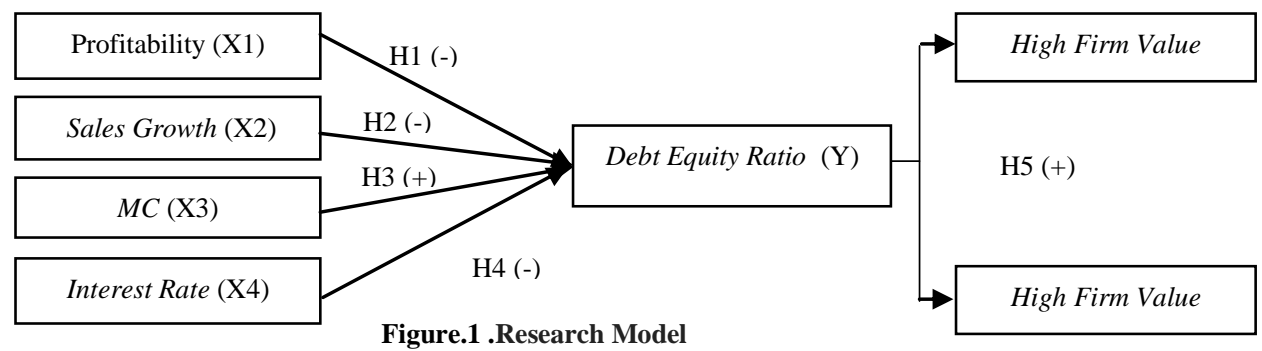

\section{RESEARCH METODOLOGY}

The data used in this study are secondary data; they are profitability data, sales growth, market capitalization, interest rates and firm value as the independent variable and capital structure (DER) as the dependent variable. The object of research is the automotive and sub-sector manufacturing companies as listed on the Indonesia Stock Exchange (IDX). The data used in this study is the panel data from 2008 to 2017. This study used a purposive sampling technique. The sampling in this study 120 samples .Measurements in this study use the classical assumption test and logistic regression models and two way anova. Data analysis techniques use classic assumption test includes normality test, autocorrelation test, multicollinearity test and heteroscedasticity test.But accordingPalacín-Sánchez et al., (2013)a normality test is not required for large sample size studies.In this study use three classic assumption tests among them autocorrelation test, multicollinearity test and heterokedasticity test. Beside testing the multicollinearity, it can be seen from the correlation matrix. If each independent variable correlated greater than 0.800 , it is considered that they have high relationship or there is an indication of multicollinearity(Ahmed Sheikh \& Wang, 2011). Theheterokedasticity test used in this study is the Glejser test. According to Aggarwal \& Padhan(2017) the occurrence of heterokedasticity is seen in the significance value of all the independent variables greater than 0.05.To detect the autocorrelation of multiple linear regression models, Durbin Watson (DW) must be 
performed. The DW statistical value will be worth two if there is no autocorrelation, zero if there is a positive autocorrelation and four if there is a negative autocorrelation. The decision of whether there is or no autocorrelation is done by setting the lower boundary value (dL) and the upper limit $(\mathrm{dU})$, then follows these conditions: If $\mathrm{DW}<\mathrm{dL}$, then there is a positive autocorrelation, if $\mathrm{dL}<\mathrm{DW}<\mathrm{dU}$, then it cannot be concluded whether there is an autocorrelation or not, if $\mathrm{dU}<\mathrm{DW}<(4-\mathrm{dU})$, then there is no autocorrelation, if $(4-\mathrm{dU})<\mathrm{DW}$ $<(4-\mathrm{dL})$, it cannot be concluded whether or not there is autocorrelation; and if DW $>$ (4-dU), then there is a negative autocorrelation(mac an Bhaird \& Lucey, 2010).

This research was conducted using a logistic regression model and annova difference test. In general, logistic regression models can be stated with $\mathrm{Li}$ as the dependent variable (if have a large debt expressed by $=1$ and do not have a large debt expressed by $=0$ ), $\mathrm{Pi}$ is a probability while $\mathrm{Xij}$ is an independent variable (profitability, growth of sales, market capitalization and interest rates).If the Sig. above 0.100, then factor analysis cannot be used or accepted. While the Sig. which is acceptable is with a minimum value of 0.05 to 0.100(Palacín-Sánchez et al., 2013). Two way anova is also called two factors variance analysis. Two-way anova compares the average difference between groups that have been divided into two variables with categorical data scale and one dependent variable with quantitative / numeric data (ratio) scale(Deari \& Deari, 2010).If the Sig. above 0.05 , then factor analysis cannot be used or accepted. While the Sig. which is acceptable is with a minimum value of 0.05 (Sedláček \& Němec, 2018).

\section{IV.RESULTS}

Table 1

Classic Assumption Result Test

\begin{tabular}{|l|l|l|l|}
\hline Tests & Indicators & Results & Statements \\
\hline Multicollinearity & $\begin{array}{l}\text { Correlation coefficient value among independent } \\
\text { variables is under } 0,800\end{array}$ & All independent variables <0,800 & No Multicollinearity \\
\hline Heteroscedasticity & Significance value $>0,05$ & All independent variables $>0,05$ & No Heteroscedasticity \\
\hline Autocorrelation & $\mathrm{dL}$ & 1,6539 & \multirow{2}{*}{ No Autocorrelation } \\
& $\mathrm{dU}$ & 1,7786 & 1,9570 \\
\hline
\end{tabular}

Source: data processing

\section{CLASSIC ASSUMPTION TEST}

Multicollinearity test has purpose to determine if the regression model found a correlation between independent variables or not; a good model should not have a high correlation between independent variables. According to Gujarati (2004), multicollinearity occurs when there is a pair-wise correlation coefficient between two repressors which is quite high, above 0.800 . The results showed that there was no multicollinearity because the coefficient value was below 0.800 . While the heteroskedasticity test aims to find out whether the regression model has an unequal variance in the confounding variable between one observation to another. If the probability value $<0.05$ then there is heteroscedasticity. The results showed that the overall probability value of the independent variables $>0.05$ so it can be said that it is free from heteroskedasticity. Autocorrelation testing is done to determine the correlation between the sorted data based on a certain time. Autocorrelation was detected with Durbin Watson (DW), the value of $\mathrm{dU}<\mathrm{d}<4-\mathrm{dU}$. Using the Durbin Watson Table with $\mathrm{N}$ (number of Samples) 132 samples, k (independent / independent variables) are 8 variables (ROA, ROA ${ }^{\mathrm{t}-1}$, ROE, GPM, growth, growth ${ }^{\mathrm{t}-1}$, market capitalization and interest rates) then obtained $\mathrm{dL}=1.6539$ and $\mathrm{dU}=1.7786$, while the DW value $=1.9572$. The results obtained from $\mathrm{dU}<\mathrm{DW}<(4-\mathrm{dU})$ are $1.6057<1.9572<2.1714$, thus, it can be concluded that autocorrelation didn't occur.

Table. 2

Descriptive Statistic Result

\begin{tabular}{lccccccccc} 
& $\begin{array}{c}\text { DER } \\
\text { (time) }\end{array}$ & ROA $(\%)$ & $\operatorname{ROA}^{\mathrm{t}-1}(\%)$ & $\mathrm{ROE}(\%)$ & $\mathrm{GPM}(\%)$ & $\begin{array}{c}\mathrm{GROWTH} \\
(\%)\end{array}$ & $\begin{array}{c}\mathrm{GRWT}^{\mathrm{t}-1} \\
(\%)\end{array}$ & $\begin{array}{c}\text { MC } \\
\text { (billion) }\end{array}$ & $\begin{array}{c}\text { Interest Rate } \\
(\%)\end{array}$ \\
\hline \hline Mean & 1.698 & 6.516 & 6.415 & 9.805 & 6.378 & 0.111 & 0.112 & 27.900 & 0.067 \\
Median & 0.960 & 4.850 & 4.850 & 10.855 & 0.220 & 0.080 & 0.080 & 27.795 & 0.070 \\
Maximum & 27.040 & 71.60 & 71.600 & 47.540 & 36.440 & 0.820 & 0.820 & 33.450 & 0.090 \\
Minimum & 0.140 & -13.400 & -13.400 & -124.1200 & 0.060 & -0.610 & -0.610 & 23.870 & 0.040
\end{tabular}




\section{DESCRIPTIVE STATISTICAL ANALYSIS}

The average value of DER is 1,699 with a minimum value of 0.140 and a maximum value of 27.04. The company that has the lowest average capital structure is INDS (Indospring Tbk) in 2017 with 0.140. It is a company incorporated in the IDX in the automotive sub-sector and components whose business oriented is motorcycle spare parts sales. With the DER value owned by INDS below 1.00, it is indicated that the company has the ability to pay long-term obligations. This is due to in 2017, PT. INDS experienced a decrease in bank loans by 43.87 than in 2016. Meanwhile the highest DER was possessed by IMAS (Indomobil Sukses InternasionalTbk) in 2007 with 27,040. It shows that the company adds debt to 27 times the amount of equity. It indicates the company has a high business risk, especially when the company is liquidated, the equity cannot cover high debt.

The average value of ROA is 5.431 with a minimum value of -13.40 and a maximum of 71.6 . The company with the lowest ROA was LPIN (PT Multi Prima Sejahtera) in 2016 of -13.40. LPIN suffered a loss of Rp. -64,037 (in million rupiah) compared to the assets owned by the company withRp. 477,838 (in millions of rupiah). The highest ROA owned by LPIN (PT Multi Prima Sejahtera) in 2017 was 71.6. ROA obtained from the 2017 net profit of Rp. 191,978 (in million rupiahs) compared to the assets owned by the company of Rp. 268,116 (in million rupiah). It shows that the profits earned in that year amounted to 71.6 times the total assets invested.

The average value of ROE is 9.80 with a range of minimum values pf -124.12 and maximum of 47.54 . The company that had the lowest ROE was LPIN (PT Multi Prima Sejahtera) in 2016 with -124.12. In 2016, LPIN suffered a loss of Rp. -64,037 (in million rupiah) compared to the total equity owned by the company of Rp. 51,595 (in millions of rupiah). The highest ROE owned by INDS (PT Indospring) in 2012 was 47.54. ROE obtained from the 2017 net profit of Rp. 540,324 (in million rupiah) compared to the company's capital ownership of Rp. 1,136,573 (in million rupiah). It shows that the profit earned in that year amounted to 47.54 times the total equity owned.

The average value of GPM is 6.378 with a minimum value of 0.060 and a maximum of 36.44 . The company that had the lowest Gross Profit Margin was PRAS (PT PRIMA ALOY STEEL) in 2007 with 0.060. In 2007 PRAS had a gross profit of Rp. 4,086 (in million rupiah) by comparing the total net sales owned by the company of Rp. 658,094 (in millions of rupiah). This year, the company did not minimize cost of goods sold, so the gross profit generated by the company was less than the net sales value. The highest GPM owned by LPIN (PT Multi Prima Sejahtera) in 2016 was 36.44. GPM obtained from gross profit in 2016 amounted to Rp. 51,659 (in million rupiahs) compared to net sales of Rp. 141,747 (in million rupiah). It shows that this year the company can minimize the cost of goods sold by 36.44 of total net sales.

The average value of sales growth is 0.110 with a minimum value of -0.607 and a maximum of 0.822 . The company that had the lowest sales growth was PRAS (Prima Alloy Steel Tbk) in 2009 with -0.607 , a manufacturing company in the consumer goods industry sector with pharmaceutical sub-sector. In 2009 PRAS decreased the sales by Rp.161,201 (in million rupiahs) compared to 2008 sales of Rp.410,673 (in million rupiahs). it shows that the low sales growth will reflect the company's revenue decline. Meanwhile the highest growth was owned by LPIN (PT Multi Prima Sejahtera Tbk) in 2016 amounting to 0.822 . It has the sales value in 2015 withRp. 77,790 (in million rupiah) experiencing an increase in sales in 2016 of Rp. 141,746 (in billion rupiah). It shows that high sales growth will increase the company revenue which affecting the company's ability to maintain profits.

The average value of market capitalization is 2,240 with a minimum value of 2,340 and a maximum of 3,360. The company that has the smallest size of the company is LPIN (PT Multi Prima Sejahtera Tbk) in 2008 amounting to 2.340 due to a decrease in share prices of Rp. 1,100 / shares from the previous year amounting to Rp. 1,600 / shares in 2007 with the same number of outstanding shares amounting to 21,250,000 shares. This shows that the company in its operational management and asset control is not well-controlled. The highest market capitalization owned by ASII (Astra International Tbk) in 2016 amounted to 3,360 dues to an increase in share prices from the previous year of Rp. 6,000 / shares to Rp. 8,275 / shares of the total outstanding shares of 40,483,553,140. The ASII company demonstrated smooth operational achievement and controlled-companyassets. The amount of market capitalization itself is a value that is owned by a company. The better a company 
in running its business, the higher the market capitalization value is. Surely, the value of market capitalization is very important because it reflects the total value of the company.

The average interest rate is 0.068 with a range between the minimum interest rate of 0.042 and the maximum interest rate of 0.092. Based on Appendix 1, the lowest interest rates occurred in 2017 WITH 0.042. According to Deputy Governor OF Bank Indonesia, Perry Warjiyo, there are four factors behind the rate cut in 2017. First, the inflation rate until mid-2017 is lower than the estimation. Second, the current account deficit remains under control, which is estimated to be at the level of $1.5-2 \%$ of gross domestic product. Third, the US Federal Reserve (The Fed) policy will raise the benchmark interest rate once in 2017. The decline in the benchmark interest rate is expected to encourage bank lending while helping companies capitalize on expanding business and making capital purchases. Whereas the highest interest rate occurred in 2008 of 0.092 due to the continued high inflationary pressure in Indonesia until August 2008, mainly due to fast-growing aggregate demand. Aggregate demand is growing fast driven by the exports and public consumption, so the strong domestic demand is driving high import growth, especially for the needs of raw materials and capital goods. This also depressed the rupiah exchange rate because of commodity price fluctuations towards economic resilience. With that condition background, Bank Indonesia made efforts to stabilize the exchange rate to avoid excessive volatility in the foreign exchange market. Of course, the effect of high interest rates makes the companies need to pay higher interest rates to creditors so that the higher the prevailing interest rates, the higher the total business debt thereby the slower the development of the business world will be.

\section{LOGISTIC REGRESSION TEST}

Table 3

Research Model Testing

\begin{tabular}{|c|c|c|}
\multicolumn{4}{|c|}{ Research Model Testing } \\
\hline Step & Chi-square & Sig. \\
\hline 1 & 2,505 & 0,962 \\
\hline \multicolumn{3}{|c|}{ Source : data processing } \\
\end{tabular}

Hypothesis testing was done using the logistic regression test in Table 3, namely: H0: Probability>0.05 means the model is able to predict the value of observation. H1: Probability $<0.05$ means that the model has a difference between the model and its observational value so that the model cannot predict its observational value. The results of the processed data show that the probability is $0.962>0.05$ means that the model can be accepted.

Table 4

Research Model Hypothesis Testing

\begin{tabular}{|l|l|l|l|}
\hline Hypothesis & \multicolumn{1}{|c|}{ Statements } & \multicolumn{1}{c|}{ Sig } & \multicolumn{1}{c|}{ Description } \\
\hline H1 & ROA affectsthe capital structure $^{\prime}$ & 0,206 & Data doesn't support hypothesis \\
\hline H1 & ROA $_{\mathrm{t}-1}$ affects the capital structure & $0,099^{*}$ & Data support hypothesis \\
\hline H1 & ROEaffects the capital structure & $0,013^{*}$ & Data support hypothesis \\
\hline H1 & GPMaffects the capital structure & 0,673 & Data doesn't support hypothesis \\
\hline H2 & Growthaffects the capital structure & $0,003^{*}$ & Data support hypothesis \\
\hline H2 & Growth t-1 affects the capital structure & $0,062^{*}$ & Data support hypothesis \\
\hline H3 & LN_MC affects the capital structure & 0,883 & Data doesn't support hypothesis \\
\hline H4 & Interest rate affects the capital structure & 0,113 & Data doesn't support hypothesis \\
\hline Constant & $-1,747$ & 0,601 & - \\
\hline \multicolumn{2}{|c|}{ Overall Percentage Correct } & \\
\hline
\end{tabular}

Source : data processing

* test results of $\alpha=0,05$

** test results of $\alpha=0,10$

The accuracy of the model formed to estimate the possibility of capital structure decisions using more dominant debt is $71.3 \%$. Thus, this model sets a fit model that can be used to predict Capital Structure that will be used in the future. The results of logistic regression determinants of companies using debt or equity which are the most dominants are ROE and Sales Growth. The logistic regression test results obtained the regression equation as follows:

DER $=-1,747-0,044 \mathrm{ROASEB} * *-0.052 \mathrm{ROE} *+4,858 \mathrm{GROWTH} *+2,423 \mathrm{GROWTHSEB} * *+\mathrm{c}$.

The first analysis of this study prove that the determinant indicators of profitability that can predict the debts usage for the automotive industry and components are ROASEB and ROE with a regression coefficient value for ROASEB of -0.044 with a Sig. of 0.099 and the regression coefficient for ROE -0.052 with the Sig. 
0.013. These results support the hypothesis that profitability has a effect, in line with the Pecking Order Theory. The higher the profitability, the larger the source of internal funding the company has so that the company requires less debt.

The second analysis prove that the sales growth is a decisive matter in the debts usage in the automotive and component industries. The results from the regression test obtained the value of the regression coefficient for growth of 4.858 with Sig. of 0.003 and also growth th $_{1}$ the regression coefficient value is 2.423 with the Sig. amounted to 0.062 . the higher sales growth rate, the higher the debt usage. This result support the hypothesis.

The third analysis prove that market capitalization variables shown the value of the regression coefficient of -0.016 with a significance level of 0.883 . The coefficient value of -0.016 means for every 1 rupiah increase in market capitalization, the capital structure (DER) will experience a decrease of -0.016 times that of own capital, assuming the other variables are constant. The significance value of 0.883 is greater than 0.05 and 0.10 . It can be said that market capitalization does not affect the capital structure (DER).

The fourth analysis prove the interest rate variables obtained the value of the regression coefficient of 31.727 with a significance level of 0,113 . The coefficient value of 31.727 means that every 1 percent increase in interest rates, the capital structure (DER) will experience an increase of 31.72 times that of own capital belongs assuming other variables are constant. The significance value of 0.113 is greater than 0.05 and 0.10 proposed by researchers, so it can be concluded that interest rates do not affect the capital structure (DER).

\section{ANOVA TEST}

Table 5

Anova Test Result

\begin{tabular}{|c|c|c|}
\hline \multicolumn{3}{|c|}{ Anova Test Result } \\
\hline & $\mathbf{F}$ & Sig \\
\hline PER & 0,14 & 0,906 \\
\hline
\end{tabular}

Difference testing is done by using anova test. Anova test is one of the comparative tests used to examine the difference in mean (average) data of more than two groups. Based on Table 9 in the appendix, the Sig value is 0.906 which means that it is greater than 0.05 , so there is no difference in the value of the company between companies either that use high debt or low debt. This strengthen the trade off theory. This means that capital structure decisions do not affect the value of the company. This result does not support the hypothesis that company value influences capital structure.

\section{DISCUSSION}

In this study the results support the hypothesis that profitability has effect, in accordance with the pecking order theory companies that has high profitability has a source of funds that are large enough so that the company requires less debt.These results support research by Khaled Ba-Abbad \& Ahmad-Zaluki (2012), Huang et al., (2011) and Velnampy \& Aloy Niresh (2012) that profitability has a negative effect. However, in contrast to the study ofNha et al., (2016), Usman \& Saleem(2015) and Orsag \& Mitar (2014) say that profitability has a positive and not significant effect on capital structure.

In the results of research says growth of sales is a determinant of the decision to use debt in the automotive and component industries.Increasing growth of sales debt usage will also increase. These results support the research conducted.Orsag \& Mitar(2014); Faez \& Kalantari (2015) and Aggarwal \& Padhan (2017). While the results of the study Nha et al., (2016); Mangafić \& Martinović (2015) and Anuar \& Chin (2016) show that sales growth has a negative and not significant effect on capital structure.

Then in this study shows that the results of the study have not been able to prove the hypothesis proposed by researchers that market capitalization has a positive effect on capital structure. This is in accordance with the pecking order theory which says that companies are more likely to use funding from internal than using external fundsso that capitalization has doesn't effect capital structure.Another possibility is that large companies that have easier access to the capital market compared to smaller companies may not be able to get funds easily in the capital market. This is because investors will buy shares or invest their capital not only by considering the size of the company, but also pay attention to other factors, such as the company's prospects, the current nature of company management and so on.By paying attention to the data in the appendix, the insignificant market 
capitalization of capital structure (DER) is possible because large market capitalization does not influence the company to use more debt, as seen from the highest market capitalization in ASII companies, but the highest DER is in companies LPIN.This shows the gap of research data because in the mindset it is said that if market capitalization is greater, the tendency to use external capital will be greater, but what happens in this study is that the higher the market capitalization, the use of external capital will also be lower. The results of this study doesn't support research by Chen (2015); Anuar \& Chin(2016) and Nha et al., (2016) which states that market capitalization can be a determining factor in the use of debt.In every use of funding sources both from internal capital and external capital, must have different capital costs and different levels of risk. It can be said that every company incorporated in the automotive industry and components on the Indonesia Stock Exchange, both companies that have large market capitalization and companies that have small market capitalization, will use more internal funding to avoid financial problems in the future. came, rather than using external funding. In addition, unstable economic conditions can also be a factor in the policy of companies incorporated in the automotive industry and components on the Indonesia Stock Exchange (IDX) in determining their capital structure.

Then in this study shows that the results of the study have not been able to prove the hypothesis proposed by researchers that interest rates have a negative effect on capital structure.Viewed from the perspective of the company, the interest rate is a component of capital costs for the company, so that rising interest rates will add to the burden of costs that must be borne by the company. Thus when interest rates increase management will respond by adjusting the level of capital structure to reduce the financial burden that must be paid.But the results of the study stated that a larger interest rate would make the company increase the use of funds from external parties. The results of this study are in accordance with the trade off theory which says that companies are more likely to use funding from external than from the use of internal funds, so interest rates have no influence on capital structure. This is likely due to fast-growing aggregate demand.Aggregate demand is growing fast because it is driven by exports and public consumption, so the strong domestic demand is driving high import growth, especially for the needs of raw materials and capital goods. So that the need for external capital also increases for the company's operational costs.By observing increased sales growth data, the use of debt is also higher.Companies with increased sales need strong funding. When the company has increased sales results, the company has the potential to get more funding because of creditor confidence in the company's revenue growth.

The high sales growth can be seen from the purchasing power of the people due to several policies issued by the government such as policies to reduce payment requirements for the purchase of a car, introduction to low-cost green cars (LCGC)cars at affordable prices and efficient use of fuel introduced at the end of 2013 .In addition there are also several opportunities that make the automotive industry grow in Indonesia, including Indonesia's stable economic growth, Indonesia still has a very low ratio of car ownership per capita.In every use of funding sources both from internal capital and external capital, must have different capital costs and different levels of risk.It can be said that each company incorporated in the automotive industry and components on the Indonesia Stock Exchange (IDX) uses external funds to be used for operational costs.

\section{RESEARCH FINDINGS}

The higher profitability of the use of corporate debt in the automotive industry and profitable components will tend to reduce the use of debt. Because increased profitability will be used to set aside profits as retained earnings. When companies have funding needs, companies will tend to use internal funding. This supports the pecking order theory that companies that have new funding needs tend to use retained earnings so that the company's risk of financial difficulties can be minimized. The results of this study indicate that sales growth (growth of sales) is high, the use of debt is higher. Companies that grow sales need strong funding. When the company has increased sales results, the company has the potential to get more funding because of creditor confidence in the company's revenue growth. The high sales growth can be seen from the purchasing power of the people due to several policies issued by the government such as the policy of lowering payment requirements for the purchase of a car, introduction of low-cost green cars (LCGC) cars at affordable prices and efficient use of fuel introduced at the end of 2013 The results of the study also provide evidence that information relating to debt financing through financial statements is not a consideration of investors when making stock purchase decisions. 


\section{Conclusions}

\section{VI.CONCLUSIONS AND RECOMMENDATIONS}

Based on the results of data analysis and discussion, it can be concluded that: The results of this study indicated that the average capital structure in the automotive industry and components shows a value of 1,699. this means that the use of debt in the capital structure in the automotive industry and components is 1,699 times greater than the equity owned. The results of this study indicated that profitability and sales growth determine the use of debt in the automotive industry and components with a significant value $<0.05$. This shows that the automotive and component industries use internal funds to run the company operations. Increased profitability and sales growth can be used for innovating in terms of creation, selection and development or improving the quality / capability of products, production processes and the implemented technologies in order to improve the company's position and help achieve the status as a world-class-quality-goods producer. In addition, the results of this study also proved that there is no difference in the value of companies that have high debt funding and low debt funding which support trade off theory. This gives the evidence that the information related to debt financing through financial report isn't becoming the investor's consideration in making stock purchase decisions.

\section{Research Limitations}

The limitation of this study is that the data used are annual data. The sample of companies used in this study was only 12 manufacturing companies of the automotive and component sub sectors as listed on the IDX. The time period used are only 10 years from 2007 to 2017. The factors that influence the capital structure used in this study only profitability, sales growth, market capitalization, interest rates and company value.

\section{Suggestions for Further Research}

For further research and academics, other variables affecting capital structure such as agency cost, financial distress, business risk, company size, asset structure, liquidity can also be added. In addition, the other industries listed on the IDX with different data analysis uses can be done for further research. The management of the companies in the automotive industry should consider the profitability factor (ROE) and growth of sales when making external funding decisions so that the company does not experience financial difficulties in the future. For investors, those who will invest through debt securities should pay attention to the level of profitability (ROE) and the growth sales that can be obtained by the company. Meanwhile, investors who will make automotive companies investment using shares should also notice the profitability and growth of sales as a picture of the business sustainability of the company.

\section{REFERENCES}

[1] Aggarwal, D., \& Padhan, P. C. (2017). Impact of Capital Structure on Firm Value: Evidence from Indian Hospitality Industry. Theoretical Economics Letters, 07(04), 982-1000. https://doi.org/10.4236/tel.2017.74067

[2] Ahmed Sheikh, N., \& Wang, Z. (2011). Determinants of capital structure: An empirical study of firms in manufacturing industry of Pakistan. Managerial Finance, 37(2), 117-133. https://doi.org/10.1108/03074351111103668

[3] Anuar, H., \& Chin, O. (2016). The Development of Debt to Equity Ratio in Capital Structure Model: A Case of Micro Franchising. Procedia Economics and Finance, 35(October 2015), 274-280. https://doi.org/10.1016/s2212-5671(16)00034-4

[4] Campus, P. J., Khan, K. I., Qadeer, F., \& Ghafoor, M. M. (2017). Debt Specialization within Profitability Sub-Groups $\square$ : A New Perspective of Debt Structure Choices Kanwal Iqbal Khan Faisal Qadeer Muhammad Mudasar Ghafoor Khan , Qadeer , Ghafoor. FWU Journal of Social Sciences, 11(2), 92-108.

[5] Chen, J. (2015). An Empirical Research: The Determining Factors of Capital Structure of Strategic Emerging Industry, Based on Data of Listed Enterprises in China. Modern Economy, 06(04), 458-464. https://doi.org/10.4236/me.2015.64043

[6] cortez and stevie. (2012). THE DETERMINANTS OF CORPORATE CAPITAL STRUCTURE: EVIDENCE FROM JAPANESE MANUFACTURING COMPANIES. Journal of International Business Research, 11(3), 122.

[7] Deari, F., \& Deari, M. (2010). Determinants of Capital Structure: Case of Companies Listed on Zagreb Stock Exchange. Zagreb International Review of Economics and Business, 13(1), 65-78.

[8] Faez, A., \& Kalantari, S. (2015). Investigation of the Effects of Capital Structure on Value of Listed Companies in Tehran Stock Exchange. Review of European Studies, 7(7), 50-58. https://doi.org/10.5539/res.v7n7p429

[9] Gill, A., Biger, N., \& Mathur, N. (2011). The Effect of Capital Structure on Profitability: Evidence from the United States. International Journal of Management, 28(4), 3-15. 
[10] Graham, J. R., \& Harvey, C. R. (2001). The theory and practice of corporate finance: Evidence from the field. Journal of Financial Economics, 60(2-3), 187-243. https://doi.org/10.1016/S0304-405X(01)00044-7

[11] Huang, B.-Y., Lin, C.-M., \& Huang, C.-M. (2011). The Influences of Ownership Structure: evidence from China. The Journal of Developing Areas, 45(1), 209-227. https://doi.org/10.1353/jda.2011.0003

[12] Khaled Ba-Abbad, \& Ahmad-Zaluki, N. A. (2012). The Determinants of Capital Structure of Qatari Listed Companies. International Journal of Academic Research in Accounting, Finance and Management Sciences, 2(2), 93-108.

[13] Kim, K. (2013). Chaebols and Their Effect on Economic Growth in South Korea. Korean Social Sciences Review, 3(2), 1. internalpdf://189.206.29.76/Chaebols and Their Effect on Growth i.pdf\%0Ahttp://qut.summon.serialssolutions.com/2.0.0/link/0/eLvHCXMwnV3fS8MwED788SKIv8XNCQe-6EPVJk1K2YPKcAriix9JE3GhNHqWv9_L2nDYIU9-FxIj-br3eXLfXcAnN09RGs-wWhJ2BJWp4YJznTOrJnFWmkur

[14] Kumar, S., \& Rao, P. (2016). Financing patterns of SMEs in India during 2006 to 2013-an empirical analysis. Journal of Small Business and Entrepreneurship, 28(2), 97-131. https://doi.org/10.1080/08276331.2015.1132513

[15] Li, L., \& Wang, Z. (2019). How does capital structure change product-market competitiveness? Evidence from Chinese firms. PLoS ONE, 14(2), 1-15. https://doi.org/10.1371/journal.pone.0210618

[16] M'ng, J. C. P., Rahman, M., \& Sannacy, S. (2017). The determinants of capital structure: Evidence from public listed companies in Malaysia, Singapore and Thailand. Cogent Economics and Finance, 5(1), 1-34. https://doi.org/10.1080/23322039.2017.1418609

[17] mac an Bhaird, C., \& Lucey, B. (2010). Determinants of capital structure in Irish SMEs. Small Business Economics, 35(3), 357-375. https://doi.org/10.1007/s11187-008-9162-6

[18] Mangafić, J., \& Martinović, D. (2015). How Micro-Level Determinants Affect the Capital Structure Choice: Evidence from Bosnia and Herzegovina. Journal of Economic and Social Studies, 5(2), 181-200. https://doi.org/10.14706/jecoss15529

[19] Nha, B. D., Loan, N. T. B., \& Nhung, N. T. T. (2016). Determinants of capital structure choice: Empirical evidence from Vietnamese listed companies. Society and Economy, 38(1), 29-45. https://doi.org/10.1556/204.2016.38.1.3

[20] Orsag, S., \& Mitar, J. (2014). Application of Cost of Capital for Capital Structuring in Croatian Firms. UTMS Journal of Economics, $5(2), 151-158$

[21] Ortqvist, Daniel Masli, Eryadi K. Rahman, Sheikh F. Selvarajah, C. (2006). Determinants of Capital Structure in New Ventures: Evidence From Swedish Longitudinal Data. Journal of Developmental Entrepreneurship, 11(04), 277-296. https://doi.org/10.1142/s1084946706000477

[22] Palacín-Sánchez, M. J., Ramírez-Herrera, L. M., \& di Pietro, F. (2013). Capital structure of SMEs in Spanish regions. Small Business Economics, 41(2), 503-519. https://doi.org/10.1007/s11187-012-9439-7

[23] Pattweekongka, S. (2014). Determinants of Capital Structure: Evidence from Thai Lodging Companies. International Journal of Arts \& Sciences, 7(4), 45-52. https://doi.org/10.5430/afr.v8n4p186

[24] Said, H. Ben. (2013). Impact of Ownership Structure on Debt Equity Ratio: A Static and a Dynamic Analytical Framework International Business Research, 6(6), 162-180. https://doi.org/10.5539/ibr.v6n6p162

[25] Sedláček, J., \& Němec, D. (2018). Interest and tax burden on corporations in the Czech industrial and banking sector after 2008. Review of Economic Perspectives, 18(4), 409-424. https://doi.org/10.2478/revecp-2018-0021

[26] Shah, A., \& Ilyas, J. (2014). Is negative profitability-leverage relation the only support for the pecking order theory in case of Pakistani Firms? Pakistan Development Review, 53(1), 33-55. https://doi.org/10.30541/v53i1pp.33-55

[27] Usman, M., \& Saleem, S. (2015). Impact of Capital Structure on Profitability Empirical Evidence of Non-Financial Firms Listed on Karachi Stock Exchange. The Pakistan Journal of Social Issues, 6(1958), 143-155.

[28] Velnampy, B. T., \& Aloy Niresh, J. (2012). The Relationship between Capital Structure \& Profitability. Type: Double Blind Peer Reviewed International Research Journal Publisher: Global Journals Inc, 12(June 2012).

[29] Zia, R. (2016). Influence of Capital Structure Choice on Firm Performance: A Case of Listed Non-Financial Firms of Pakistan. JHSS, $X X I V(1)$. 